\title{
POETIC THOUGHT AND EXPRESSION POSSIBILITIES IN UZBEK NOVELS
}

\author{
Islamjon Axmedjanovich Yakubov \\ Associate Professor on the Science of Philology of the Tashkent State \\ Pedagogical University named after Nizomi
}

Article DOI: https://doi.org/10.36713/epra2250

\begin{abstract}
In this article poetic innovations on the novel writing during the years of national independence have been presented by dividing into periodicals of the development period of Uzbek novel writing. Objective and subjective basics of the development of genre, social-genetic roots and literary-aesthetic sources have been defined. Quality-structural changes occurred in the character of the Uzbek novel writing, the ways of conveying the essence of human has been investigated. The impact of the different aesthetic point of views which were collided with the outlook of the Uzbek novelists and the form and content of genre facing with the process of transformation on national bases and its influence to the expression mode have been learnt.

KEY WORDS: literary progression, realistic novel, jadid movement, form, style (method), poetic intelligence, symbol, polyphony, intellect, poetic innovation, pluralistic thought, existentialism, diffusion of genres, architectonics, neonovel, experiment, psychoanalyze.
\end{abstract}

\section{INTRODUCTION}

For thousands years, especially Uzbek literature which has been developing in the scope of Eastern literature, culture from the end of the XIX ${ }^{\text {th }}$ century and from the beginning of the $\mathrm{XX}^{\text {th }}$ century started to grasp the new spiritual world - experience of the European literature. The realistic novel writing genre which had over a century history in the Uzbek Literature can be divided into the following three huge periods in conditionally: 1 . Novel writing in the period of Jadid movement; 2 . Novel writing in the period of Soviet time; 3. Novel writing in the period of Independence.

The new poetic changes which had been occurred in the nature of Uzbek novel writing in the period of Independence to be stated in this article by us.

\section{MAIN TEXT}

At the $70^{\text {th }}$ of the previous century uzbek novel writing which was observed connecting with the names as A. Mukhtor, O. Yoqubov, P.Qodirov, U. Usmonov, S. Ahmad, Sh. Kholmirzaev, U. Hoshimov, refreshed "explosion period" literery-cultural climate was raised up new phase in the second half of the $80^{\text {th }}$. By standing at the stage of the native land, in the development of the novel genre glancing at the public humanitarian border had been widen ding and its quality had been increased. That was happened relating with the authors' return to the national source and changing the mode of description of human into specific spiritual stratum. One can say that the novel "Lolazor" ("Tulip field") (1988) by Murod Muhammad Dust was the first artwork which caused to begin this process. Because taking into consideration the literary heroes' specific individual characters and expressing them as a person of thoughts have been raised just after this novel appeared. The economic-moral, political-ideological recession of the stagnation period has been revealed by the language of gestures.

The life, thoughts of Nazar Yakhshibaev in the novel "Lolazor" and his self checking as a person of conscience and honesty made the reader both to sympathize with him and feel sorry for him. The soul distress of the hero who was accounting for his joy and sorrow while being in the hospital has been investigated either a warm kindness or anger, sometimes with a sensitive criticism, gesturing and irony in the polyphonic melodiousness. This was a psychological investigation of the problems of a native person and time, the other word it was a new approach to the interaction of human and authenticity.

So the national novel has been richen with the new specifics of genre basing on many factors as real life, the thought manner of creator, the reader's moralspiritual needs, self progressive development, the scope and level of mastering and effecting. Actually, having started to get acquainted with the profound literary works belonged to many literary schools and methodological trends in the world literature, the Uzbek readers have not been satisfying with one styled novels created on the method of socio-realism. The changes and enlargement of the reader imagination appealed to the writers to decline ready stereotypes. As a result according to their philosophic-ideological contents the artworks belonged to diverse trends have been appeared. 
For instance the number of novels depicted Islamic, religious-clergy interpretation have been raised. One of these artworks is the novel dilogy "Navoi and an artist Abulhayr" (2006) by O. Muktor. In this novel the author found the character of soul by seeking the logics of life inside the poetic world created by Alisher Navoi. The persons' broken heart, complicated mood and incurable malady have been realized by tightly connecting with the beliefs of the faithfulness holy men. That's why Navoi appeared before the eyes of reader with his beautiful thoughts and nice wishes, sweet memories and guiltiness regret. That is showed that O. Mukhtor didn't realize Navoi as a "prudent" person in the centre of cultural-educational and socialpolitical activities of the previous period of our novel writing, but there were changes for the better on investigating and analyzing the great humanist in prose. The artwork gives an opportunity to realize Navoi much better, to feel him according to his thought style, moral patience and his way of beliefs. Because in such kind of artworks the person has not been intensely binded with social-historical condition, state, policy and leading ideology. But it is expressed from the point of thought style, its natural and genetic roots, divine essence, merits-demerits.

This situation is not a result of absolute chance. Except, modern Uzbek literature, especially prose has been striven for examining the spiritual periphery of the human, investigating unremarkable sense in his mentality. And the process of realizing Navoi is going on parallel with this. Generally this novel-dilogy is not only high and more perfect stylistic success of the writer, but it is peculiar literary experience in the world of investigations on learning Navoi, as such it is also an important innovation in the development of the Uzbek literature.

The characters some of our novels became a tragic characters who controlled by themselves and criticized their past life. For example, in the novel "Adolat manzili" (Justice Haven) (Odil Yoqubov. (1994) Tanlangan asarlar (Selected artworks). Four volumed. Volume I.). the writer sharply declined the efforts of former Soviet government by a wise and strong old man, dedicated his life and fate for his beliefs who made a conclusion about the attitude of the society to the fate of human. Through divulging bad ways and tricks of political-legal forces that were in the mood of colonization their real figures were vividly depicted. The veteran who dedicated his half century life to the activities of the Soviet government while meeting with the dishonest, harmful, sinful, unfair and fraudulent officials feeling himself weak and said with regret: "No, there is not existed the Soviet government any more!... It is foolish my half century life dedicated to this government!" Here the views of the veteran about the honesty, fair, beliefs, human fate sharply differed from the characters of the writer in his previous novels as Normurod domla, Shorahim shovvoz and others.

The epoch which realized that the Soviet system had no future, the founded theory was collapsed, the first it was a reawaken of the national thoughts, the second it was the depiction of the nonsense life of people who dedicated his life and wisdom to the strives of that society and recognizing the spiritual needs of the reader. That's why drew a special attention to the nonsense of the followed theories, environment where the characters lived, dedicated life to it in the novels like "Olabuji" ("Bogyman"), "Dinosaur" by Sh. Kholmirzaev, "Ming bir qiyofa" ("One thousand figures") by O. Mukhtor, "Otamdan qolgan dalalar" ("The fields inherited from my father"), "Bu dunyoda o'lib bo'lmaydi" ("It's impossible to die in this world") by T. Murod.

National novel is not only being richen basing on inner development by the experience gained along the years, but it is being enriched through integration the specific features of the most literary genre into its nature. For instance, various genres as an anecdote, a story, a legend, a myth, a fairytale, an ancient sayings, a letter, moral-didactic and love-romantic, religious, autobiographic oral epic artworks, scientific research work, historical chronologies, journalistic, philosophical passages have been artistically covered classified basing on the specific literary-aesthetic aims. The novel was subordinated to the ideological-literary and philosophical conception.

For example, in the architecture and the style of depiction in the novel "Ikki eshik orasi" (Utkir Hoshimov (1989) Ikki eshik orasi (Between two doors). ("Between two doors") by U. Hoshimov one can observe the transformation of development tendencies which were started from the novel "Chinor" ("Plane tree") (Asqad Muktor.(1969) Chinor (Plane tree). Novel) by A. Mukhtor and raised up the new stages in the second half of the $80^{\text {th }}$, especially story mode and style renewing. So observing the novel by the embrace of the above mentioned process gives an opportunity to discover its essence more deep. In the novel one can notice the influence of stories and myth taken place in "Shohnoma" by Firdavsi and folk tales "Hudoynamak". And also literary traditions extra story compositional range in the love-adventure oral epic "Sabbai Sayyor" by Alisher Navoi, "Hasht bihisht" by Khisrav Dehlaviy, "Haft paykar" by Nizomi connecting with the using of self story to be assimilated. The conflicts which happened in the spirit of the characters in those artworks, the new approaches to the style of expression are used creatively. It is indicated that the eastern spirit has been clearly demonstrated in the novel and it is a national-aesthetic phenomena of the artwork.

In the novel "Ming bir qiyofa" ("Thousands of figures") (Omon Mukhtor. (2000) To'rt tomon qibla (Four sides are qibla). Trilogy) by O. Mukhtor relating with Nasriddin who decided to go to Kultepa and his donkey was given the story "The childhood of Afandi". In the novel "Egilgan bosh" ("Leaning head") (Omon Mukhtor (2000) Xotin podshoh (The Wife Queen). Novels) was used the fairytale "Mullaning boshi bormidi?" ("Has the mulla a head?"), and the saying about the traveler in the sea. In the "Ko'zgu oldidagi 
odam" ("The men in front of the mirror") the events relating with the magic mirror, in "Aflotun" (Omon Mukhtor. (1998) Aflotun. Novel) used the motiveepisode about the mysterious well. In the "Tepalikdagi xaroba" ("The Ruin over the hill") we met the strange adventures related with the memory and dream flights. In the novel "Ffu" there is a depiction of the episodes a sudden disappearance of a beautiful palace and the "sorcery" of Haydar Makhsum. In the novel "Ayollar mamlakati va saltanati" ("The Land and Reign of Women") (Omon Mukhtor (2000) The Land and Reign of Women. Novels.) we are witnessed to the impact of the folktale "Bir yolg'onda qirq yolg'on" ("Forty lie under the one lie"), and the anecdotes concerning to beliefs of Afandi and the melody belonged to fairytale.

The novel "Ffu" is a style of legend and there is depicted the fight between the sympathy and evil. In "The Land and Reign of the Women" true story was a priority level. In "Aflotun" the degradation of the human thoughts and the process of its reborn had been expressed by giving new form to the plot of fairytale. In the "Thousands of figure" reset the life and love history of Lutfi. In "The Ruin over the Hill" depicted the characters of Akbar, Amur Temur, Bobur, Mirza G'olib, Byron and Mashrab. We met with Nodirabegim in the artwork "The Land and Reign of the Women", the characters as Bahovuddin Naqshband, Fayzulla Khuja, Abdurauf Fitrat, Ismoil Somoni in the novel "Aflotun". In "Odamlar kulishlari kerak" ("People should laugh") (Omon Mukhtor (2008) People should laugh) the historic image of Sher Muhammad Bek was depicted. The writer by setting such kind of characters basing on perfect family tree and he got creative support and proof which belonged to them.

It is clear that the novels of O.Mukhtor are the results of deep understanding the content value of classical literature and integration of thoughts, dream, memory with the reality, effective usage of the folk samples, legends and fairytale models, combining with the eastern national spirit and philosophy. So it is impossible to describe their form, structure of the plot and the style of expression without such kind of national roots.

Basically, most of the heroes of the author have the specific sacred features and they are the PERFECT PEOPLE who thought about the aim and sense of living, the problems of people and their inner world. Uzbek novels from the point of view with its aspects (local colour, national spirit, complicated spiritual imagination style which belongs only to our Uzbeks and the reflection of either its sides or describing the person as a complex system, language, architectonics, basing on the ideas and thoughts and etc) and also with their whole content are the real national phenomena.

Actually, different aesthetic point of views by meeting with the outlook of the writer first and then get transformation on the national basics. As we mentioned above mixing up the legends, stories, oral epics, sample of poems, fantasy land and reality and other sides became perfect on the eastern basics as the collapsing of the heroes, strengthening the ironical content and so on. So contemporary our novel writing is not separated from the valuable sources belonged to the Eastern thoughts, folklore and ancient Uzbek prose and also jaded literature which was the progressive pages of our literature.

At present time the human and his life, the depiction and investigation made connections the content of the national novels with the fate of human, nation, society and history. And it is provided the development of the artworks in the type of novel-tetra logy as "Ulug' saltanat" ("The Great Sultanate") (Muhammad Ali. (2003) Ulug' saltanat (The Great Sultanate). First book. Jahongir Mirzo) by Muhammad Ali.

Such kind of specific quality-structural changes regarding to the diffusion of genre renewed the form of genre and increased the opportunity of literary depiction. The characters of the novel also sharply changed as a historical-cultural type. The scope of conflicts belonged to the outer reality moved into the inner soul of person. And now the fate of the hero are not defined not only by the reality, but the free plot, the trend of "consciousness and thoughts" is also provided the specific characters concerning to the human. It is impossible to impact the form and content, the style of expression through such kind of situation. Because the novel is the genre interpreted the world according to the desire of the author - "subjective epopee" (Goethe I.V. (1980) Selected artworks. Ten volumed. V. 10). There is not reflected only reality, but also reflected the feelings. The epic distance is not always kept in the novel. It has a wide opportunity for completely changing the modern coordination of the genre (Bakhtin M.M. (1986) Epos and novel// Literary-critical article). There is no single poetic rule (Kojinov V. (1964) Novel - epos of the new time.// Theory of the Literature). So the novel is a real literary event which is formulated and increased in reality.

The novel is a genre indicated the leading literary form and level of perfect ness of each national literature. In the world novel writing the types of genre and possibilities of the novel has been completely changed in the $70^{\text {th }}$ of the previous century, as to our literature this process have taken place during the years of national independence, its content has become more thick and started to appear the compact novels according to the structure and analytical novels according to the content. That was happened because of the assimilating the specific features of experimental researches relating with the genre novel conducted by N. Carrot, A. Rob- Grey, M. Butter, K. Simon and their followers F. Solvers, G. Richard and others in the $50^{\text {th }}$ $70^{\text {th }}$ of the $\mathrm{XX}^{\text {th }}$ century. Besides the desire for drawing more attention to the person than giving odd descriptions of novelists increased the demands for the compact novels.

It is known that traditional novel generally the epos has described the conception of a person by 
keeping him in the centre of the artwork and interpreted it literarily. "New novel" based on the life experience of the author, the most personal-subjective free thoughtsideas passed from his mind and soul prism. The composition and content of the artwork differed with its specific features as it should be freed from limits and always not made complete solution. For example, in the artwork of A. Rob-Grey the outer world items depicted with objectively and marked. The novels of N. Sarrot depicted the dialogic elements of the mysterious thoughts which have been occurred inner side of mind. The polyphonic novels of M. Butter the thoughts which seemed dispersed outwardly combined with a single version based on the rules of mosaic.

Such kind of views caused to change our traditional point of views about the novel and made a certain reforms. As a result the tastes of the readers also adapted to the "new novels" with the world novel writing experience synthesized national-cultural basics and literary editing regarding to the symbol- images. Because in the content of such kind of novels laid the fate of nation, Motherland and people, the intellectual level of our contemporary person who sought the logics in the life of human. In the complicated world the role of human being has been recognized in different level. We hope that it will serve for sharpening to realize the essence of himself as a created human in the same line of future plans and high civilization achievements. A fifty two paged novel "Boqiy darbadar" ("Eternity Indigent") (Isajon Sultonov (2010) Boqiy darbadar (Eternity Indigent). Novel,) written by the writer Isajon Sulton depicted the character of the person as the symbol of who stood against the highest decision of the God and always around his own fate. In this artwork was appreciated not only the honesty and helplessness of the people, but also glorified the power, punishment, curse or mercy of the Creator, in the wide meaning his grand occasion which is higher than the eternity to be respected. In this novel synthesized the life giving principles observed in the creative work of the novel writers as Ch. Aytmatov, O. Muktor, A. Dilmurodov, Kh. Dusrmuhammad, U. Hamdam in the specific style. Isajon Sultonov addressed not only to the sayings of "Koran Kareem", but he addressed to the problems of folklore and ethnography, astrology and history, geneticist engineering - new modeling of the hereditary program of molecular genetics, the theory and practice of cloning of gene, the right of death (euthanasia) of the human beings. He used the achievements of sciences and technology fruitfully in the field of novel writing.

From the end of the previous century the attempts of the authors for ridding of vary ideological chains increased the needs to the psychoanalysis. Uzbek novelists tried to explain social relations and the essence of social structure basing on psychic factors. In such novels the social behavior has been interpreted connecting with the genetic factors specifically appropriate only the human psychogenic. Direct interrelations of people were analyzed. In the novel writing began to draw a great attention to the logical symbols. Under this view there is an idea that the objective world and nature belonged to empriocriticism existed depending on the mind "I". Using this methodological principles of sociology based on the following view - the human and nature could not been separated, they closely interconnected with each other, but the natural laws have been created basing on the spiritual needs of people.

The second, the theory of psychoanalytic association of $Z$. Frade, the teachings "Humanism psychoanalysis" of E. Froum to be assimilated. As a result their wide usage the artworks as "Adolat manzili" (Justice Haven) by O. Yoqubov, "Bozor" (Market) (Khurshid Dustmuhammad (2010) Bozor. Novel) by Kh. Dustmuhammad, "To'rt tomon qibla" by O. Mukhtor, "Kapalaklar o'yini”" (The dance of Butterflies) (Tuxtamurod Rustam (2000) Kapalaklar o'yini. Novel) by $\mathrm{T}$. Rustam appeared in the Uzbek novel writing. In these novels the attempts for analyzing the personality of the hero, his innate feelings, thinking mode, honestly self-observation and formulating various ideas, genetic relations with the ancestors began to be observed.

Generally, psychoanalysis which is being acquired on national-cultural basics in the sphere of novel have given an opportunity for effective using of symbolic tools, interpretation of the social process by interrelations, ethics-modesty, aesthetics, human philosophy, international cooperation, wide and deep analysis of special problems related with the inner feelings, making the literary language diverse.

Observation the existing literary process defined that the national novel writing is not developing only in the traditional realistic sphere. Hopely can say that even in this field there is happened digression of old thoughts. As to us the main cause for this is not to be limited on analyzing the human only by socially, investigating things and events only reasonable connections - the principles of historical-psychological determinism.

The volume size of the novels by Muhammad Ali is just like as the volume size epopee. The problems having public importance have been perceived with the example of Amur Temur and Temurieds period phase by the literary range, basing on the complex plot. Appropriately to this the events have taken place in the hearth and time. The importance is that in the tetra logy the reality depicted in the realistically and lyricromantic style with the help of the events which have been observed by the author, understanding basing on his ideal and creatively rewritten.

In the novels of Omon Mukhtor the association that has been gone in the thoughts and soul of our contemporary fellow who are striving to realize the problems between the human and universe has been revealed through the retrospective plot. For example, in the novel "Navoi and artist Abulkhair" (Omon Mukhtor (2003) Navoiy va rassom Abulxayir. (Navoi and artist Abulkhair). Novels) to be observed the principles of literary understanding the way of saving the unity soul and body while facing with the bitter world verity, 
getting the power from the feeling of patience and thanks, the way of defending himself by comparing history and time. Such kind of situation we can meet in the novel "Bu dunyoda o'lub bo'lmaydi" (It's impossible to die in this world) (Togay Murod (2001)Bu dunyoda o'lib bo'lmaydi. (It's impossible to die in this world). Novels) T. Murod.

As to the novels of Asad Dilmurod either historical or mystic-romantic, sometimes the spirit of sharp psychology achieved domination. The author in the novel "Fano dashtidagi qush" ("A Bird in the sky plain") (Asad Dilmurod (2002) Fano dashtidagi qush. (A Bird in the sky plain). Novel) in the sphere of realistic novel boldly using the style of mythic romantics, but in his next artworks he avoided the way of making "an experiment". He began to strive investigating the hollows in the social-cultural life surrounded us clearly and embodying his own ideas through the long history and the trustful real people. Historical-literary materials became a tool of proofing himself for the nation, finding the way to the soul of people from the reality, expressing aesthetic ideas which caused to intend them to be honest and courageous. That's why A. Dilmurod mostly strived to the aesthetic essence rather than details.

The story "Yolg'izlik" ("Loneliness") (Ulug'bek Hamdam (1998) Yolg'izlik (Loneliness). Narratives and stories) of U. Hamdam despite being a mega artwork that can be a guide for all his works, he followed integrating the principles of realistic depiction in "Muvozanat" ("Balance") (Ulug'bek Hamdam (2007) Muvozanat (Balance). Novel), symbolic-allegorical in the "Isyon va itoat" ("Revolt and Obedience") (Ulug'bek Hamdam (2003) Isyon va itoat (Revolt and Obedience). Novel), lyric-romantic and symbolicallegorical in "Sabo va Samandar" ("Sabo and Samandar") (Ulug'bek Hamdam (2007) Sabo and Samandar. Novel ). The writer in the field of novel analyzed the basics of the conflicts between the national estimation and outlook.

In fact, today the most novelists through writing sincerely as much as it possible try at first to give spiritual power the pureness in their soul, at second to strengthen the readers belief and make changes in their soul. Realizing themselves, perfect ness of belief, the feeling of responsibility not only conscience and soul, but in front of the Creator has been found its meaning and depiction.

\section{CONCLUSION}

Uzbek novels created in the last years besides the attitude and point of view of the writer several characters rather unrepeatable outlook interrelated with the human adornment and environment in essence found its self expression. Through this complicated, stratum conflict able specific dramatics between the characters of the person, people and universe, people and historical environment, people and time have been reflected. Harmonies of the genre with the life of people, his economical, social and global joy and sorrow which are occurring in his moral-spiritual world provided them to be rich in ideas and thoughts.

Observing the novels as "Otamdan qolgan dalalar" ("The fields inherited from my father"), "Bu dunyoda o'lib bo'lmaydi" ("It's impossible to die in this world") "Olabuji" ("Bogyman"), "Dinosaur", "Jimjitlik" ("Silence"), "Oqqushlar oppoq qushlar", "White Birds" showed that today's Uzbek novelists literarily understand the choke of initiative and creation in the character of the nation caused to appearing negative factors as his adaptation to the unfair an inability ness in his outlook, accepting social disgrace as a usual situation. Actually, depicting objective figure of the disgraced people and striving to express main roots of the tragedy is the clear note of national novel writing which is reawaken in the years of Independence.

So the main feature of the modern Uzbek novel writing is that the human became a target issue for them. It is true that the changing the nations style on realizing the world the results of thoughts in the novels played a significant role.

\section{REFERENCES}

1. Asqad Muktor. Chinor (Plane tree). Novel. Tashkent: Uzbliterary publishing. 1969

2. Bakhtin M.M. Epos and novel// Literary-critical article. - M., 1986

3. Goethe I.V. Selected artworks. A ten volumed. V. 10. M. 1980.

4. Isajon Sultonov. Boqiy darbadar (Eternity Indigent). Novel // Sharq Yulduzi, 2010, № 6.

5. Kojinov V. Novel - epos of the new timel/ Theory of the Literature. - M. 1964

6. Murod Muhammad Do'st. Galatepa qissalari. Tashkent: Yosh gvardiya, 1985.

7. Muhammad Ali. Ulug' saltanat (The Great Sultanate). First book. Jahongir Mirzo. - Tashkent: "Sharq" Head Editing House, 2003; Second book. Umarshakh Mirzo. - Tashkent: "Sharq" Head Editing House, 2006; Third book. Mironshoh Mirzo. - Tashkent: "Sharq" Head Editing House, 2010; (Up today three books of novel-tetra logy have been published. I.Ya)

8. Odil Yoqubov. Tanlangan asarlar (Selected artworks). Four volumed. Volume I. - Tashkent: "Sharq" Head Editing House, 2005. p. 5- 178

9. Omon Mukhtor. To'rt tomon qibla (Four sides are qibla). Trilogy. - Tashkent: "Sharq" Head Editing House, 2000 - p. 9-162.

10. Omon Mukhtor People should laugh. - Tashkent: Ma'naviyat, 2008.

11. Omon Mukhtor. Navoiy va rassom Abulxayir. (Navoi and artist Abulkhair). Novels. - Tashkent: "Sharq" Head Editing House, 2006

12. Khurshid Dustmuhammad. Bozor., Novel. Tashkent: "Sharq" Head Editing House, 2000.

13. Tog'ay Murod. Otamdan qolgan dalalar. Novel. Tashkent: "Sharq" Head Editing House, 1994.

14. Togay Murod. Bu dunyoda o'lib bo'lmaydi. (It's impossible to die in this world). Novels. - Tashkent: "Sharq" Head Editing House, 2001 
15. Tuxtamurod Rustam. Kapalaklar o'yini. Novel. Tashkent: "Sharq" Head Editing House, 2000.

16. Asad Dilmurod. Fano dashtidagi qush. (A Bird in the sky plain). Novel. - Tashkent: - Tashkent: "Sharq" Head Editing House, 2002.

17. Ulug'bek Hamdam. Yolg'izlik (Loneliness). Narratives and stories. - Tashkent: QatortolKamolot, 1998.

18. Ulug'bek Hamdam. Muvozanat (Balance). Novel. Tashkent: "Sharq" Head Editing House, 2007.

19. Ulug'bek Hamdam. Isyon va itoat (Revolt and Obedience). Novel. - Tashkent: Yangi asr avlodi, 2003.

20. Ulug'bek Hamdam. Sabo and Samandar. Novel. Tashkent: Muharrir, 2009

21. Utkir Hoshimov. Ikki eshik orasi (Between two doors). Novel. - Tashkent: Literature and Art Publishing House named after Gafur Gulam, 1989

22. Shukur Kholmirzaev. Olabo'ji. Novel //Sharq yulduzi, 1992. № 1-4.

23. Shukur Kholmirzaev. Dinazavr. Novel // Yoshlik, 1996. № 2-4 